\title{
Intraoperative validation of Left internal mammary artery Graft by Fluorescence Imaging Technique
}

\author{
MG Kibria, AM Asif Rahim*, MAH Pervez, T Ahmed, MSH Talukder, A Zaman, QM Hoque \\ From World Society of Cardiothoracic Surgeons 25th Anniversary Congress, Edinburgh \\ Edinburgh, UK. 19-22 September 2015
}

\section{Background/Introduction}

In Surgical revascularization by CABG surgery Left internal mammary artery (LIMA) to Lt.ant.descending (LAD) is considered gold standard conduit of choice for myocardial revascularization. Although conventional angiography is gold standard for assessing graft patency but rarely available in operating room in Bangladesh. So intraoperative florescence imaging (Novadaq Technologies SPY TM System IFI)0 is an angiography like imaging using fluorescence indocyanine green excited laser light, (ICG) this device permits validation of graft patency intraoperatively.

\section{Aims/Objectives}

To ensure patency after completion of graft and do revisions if necessary peroperatively when chest is open is mandatory for implementation of one of the techniques for intraoperative graft validation in Bangladesh. IFI is the safe, cost-effective, less time consuming and has no radiation risk. So the aim was to evaluate the intraoperative fluorescence imaging (IFI) system in the real-time assessment of graft patency during CABG to ensure the highest quality of the surgery and evaluate feasibility of the IFI to visualize flow in the native and grafted vessels in CABG specifically LIMA to LAD.

\section{Method}

It was a descriptive cross sectional study at NICVD between July 2013 to June 2014 NICVD on Spy TM System (IFI) in CABG surgery focused on 36 patients' LIMA to LAD grafts.

Department of Cardiovascular Surgery, National Institute of Cardiovascular Disease, Dhaka, Bangladesh

\section{Results}

Of the total 36 patient's mean age $54 \pm 8.38$ years, body mass index $25.87 \pm 2.39$. The quality of LIMA to LAD graft were assessed by using. Quality of anastomosis were assessed intraoperatively to validate graft. peroperative assessment of LIMA to LAD by IFI system revealed $32(88.8 \%)$ patent anastomosis, Narrowing of anastomosis $2(5.55 \%)$ stenosis of the anastomosis in 2(5.55\%).

\section{Discussion/Conclusion}

Using IFI system is a best way to validate patency of LIMA graft intraoperatively. Since it does not have any adverse effect may become the gold standard for surgical management in the near future.

Published: 16 December 2015

\section{doi:10.1186/1749-8090-10-S1-A1}

Cite this article as: Kibria et al:: Intraoperative validation of Left internal mammary artery Graft by Fluorescence Imaging Technique. Journal of Cardiothoracic Surgery 2015 10(Suppl 1):A1.

Submit your next manuscript to BioMed Central and take full advantage of:

- Convenient online submission

- Thorough peer review

- No space constraints or color figure charges

- Immediate publication on acceptance

- Inclusion in PubMed, CAS, Scopus and Google Scholar

- Research which is freely available for redistribution 